\title{
PERIODONTAL EVALUATION OF STOCK AND CUSTOM CAD/CAM IMPLANT ABUTMENTS: 1-year follow-up study
}

\author{
Ivica Pelivan1, Ivan Separovic², Niksa Dulcic, Dragana Gabric ${ }^{3}$, Slavica Sovic ${ }^{4}$ \\ ${ }^{1}$ Assist. Prof., School of Dental Medicine, University of Zagreb, Department of Removable Prosthodontics, Zagreb, Croatia \\ ${ }^{2}$ Cand. Med. Dent., School of Dental Medicine, University of Zagreb, Zagreb, Croatia \\ ${ }^{3}$ Assist. Prof., School of Dental Medicine, University of Zagreb, Department of Oral Surgery, Zagreb, Croatia \\ ${ }^{4}$ PhD., Andrija Stampar School of Public Health, School of Medicine, University of Zagreb, Zagreb, Croatia
}

\section{Background}

Implant abutment selection is the crucial moment in implant prosthodontics treatment. Abutments can generally be divided into two main groups: stock and custom. For several years, stock abutments have been the only option available for clinicians.

Custom made CAD/CAM abutment acts as adequate support for soft tissues, and the connection between abutment and a cement-retained crown is moved more towards coronal, which makes residual cement removal easier during cementation of a prosthetic restoration.

\section{Aim/Hypothesis}

The aim of this study was to compare stock and individual CAD/CAM abutments after one year in function. A total of 64 subjects with one missing tooth, were included in this study. The missing tooth was replaced with a dental implant, an abutment and a porcelain-fused-to-metal crown.

\section{Materials and Methods}

A total of 64 subjects had a single tooth loss restored by dental implant and porcelain-fused-to-metal crowns were fabricated. In one group there were a total of 34 stock Ti abutments and in the second group of subjects 30 CAD/CAM made Ti abutments. Examination of soft tissues around dental implants included determination of modified plaque index ( $\mathrm{mPI}$ ) and modified bleeding index ( $\mathrm{mBI})$, as well as measurement of sulcus probing depth (PPD). The average modified plaque index (mAPI) was calculated from the measured values, as the average measurement value on all four crown surfaces.
The average modified bleeding index (mABI) was calculated in the same way. PPD measurement was performed on the mesial, distal, vestibular and lingual crown surface, and the average values of measured probing depth (APPD) were calculated. The values mAPI, $m A B I$ and APPD were measured during the first checkup (a week after cementing the crown) and at check-ups after four, eight and twelve months.

\section{Results}

Average plaque index values (API), initial and after four, eight and twelve months, have not indicated significant differences between two groups of subjects. Average bleeding index values - initial (i-ABI) and after four months $(4 \mathrm{~m}-\mathrm{ABI})$ revealed no significant differences between two tested groups. However, there was significant difference in the average bleeding index values after eight months ( $8 \mathrm{~m}-\mathrm{ABI})$ between the two tested groups (Mann Whitney's $U$ test $p=0.002$ ). Significant difference (Mann Whitney's $U$ test $p<0.001$ ) was also observed for the average bleeding index values after twelve months (12m-ABI) between the two groups of subjects. There was no significant difference in the mean values of probing depths between two groups of subjects.

\section{Conclusion and Clinical Implications}

The results of this study showed that the impact of the abutment type (individual CAD/CAM or stock) on the average bleeding on probing was significant, especially after eight or twelve months. The level of oral hygiene showed significant correlation with the average bleeding on probing.

\begin{tabular}{|c|c|c|c|c|c|}
\hline & & $\mathrm{i}-\mathrm{ABI}$ & $4 m-A B I$ & $8 \mathrm{~m}-\mathrm{ABI}$ & 12m-ABI \\
\hline STOCK & $\begin{array}{l}\text { Median } \\
\text { Range }\end{array}$ & $\begin{array}{c}0.25 \\
0-2\end{array}$ & $\begin{array}{l}0.125 \\
0-2.5\end{array}$ & $\begin{array}{c}0.5 \\
0-1.25\end{array}$ & $\begin{array}{c}0.5 \\
0-1.75\end{array}$ \\
\hline custom & $\begin{array}{l}\text { Median } \\
\text { Range }\end{array}$ & $\begin{array}{c}0.25 \\
0-1.25\end{array}$ & $\begin{array}{c}0 \\
0-0.75\end{array}$ & $\begin{array}{c}0 \\
0-0.5\end{array}$ & $\begin{array}{c}0 \\
0-0.5\end{array}$ \\
\hline Mann Whitney's U test & $\mathrm{P}$ & 0.427 & 0.132 & 0.002 & $<0.001$ \\
\hline $\begin{array}{l}\text { Total for all subjects } \\
\text { (STOCK+CUSTOM) }\end{array}$ & $\begin{array}{l}\text { Median } \\
\text { Range }\end{array}$ & $\begin{array}{c}0.25 \\
0-2\end{array}$ & $\begin{array}{c}0 \\
0-2.5\end{array}$ & $\begin{array}{c}0.25 \\
0-1.25\end{array}$ & $\begin{array}{c}0.25 \\
0-1.75\end{array}$ \\
\hline $\begin{array}{c}\text { Friedman's two-way analysis of } \\
\text { variance for repeated } \\
\text { measurements }\end{array}$ & $\begin{array}{c}\chi^{2} \text { (number of } \\
\text { degrees of freedom) } \\
\text { P }\end{array}$ & $\begin{array}{l}\chi^{2}=3.15 \text { (3); } \\
P=0.369\end{array}$ & & & \\
\hline
\end{tabular}

